\title{
Towards Enriching Quality of Life in School Environments: An analysis of educational policy in India
}

\author{
Smita Khan \\ Visveswaraya National Institute of Technology, Nagpur, India. 440022 \\ smitakhan@gmail.com
}

\begin{abstract}
This paper critically examines the objectives of policy manifest in NCF-2005 for its directions and attitude towards school design. It identifies grey areas in understanding of the concept by policy makers. The paper advocates remedying policy-based lacunae for an improved QoL by an extended appreciation of the concepts stated in NCF 2005 from the point of view of child centricity. The study strongly recommends inclusion of architects and planners in the policy-making process.
\end{abstract}

Keywords: Quality of life; school environs; child centricity; curriculum policy

eISSN: 2398-4279 @ 2016. The Authors. Published for AMER ABRA by e-International Publishing House, Ltd., UK.. This is an open access article under the CC BY-NC-ND license (http://creativecommons.org/licenses/by-ncnd/4.0/). Peer-review under responsibility of AMER (Association of Malaysian Environment-Behaviour Researchers), ABRA (Association of Behavioural Researchers on Asians) and cE-Bs (Centre for EnvironmentBehaviour Studies), Faculty of Architecture, Planning \& Surveying, Universiti Teknologi MARA, Malaysia.

https://doi.org/10.21834/ajqol.v1i1.34 


\subsection{Introduction}

The concept of 'Quality of Life' is wide- ranging, interdisciplinary and fuzzy (Marans, 2012). It aims at the overall well-being of society. 'Quality of Urban Life' discourses upon spatial factors of the built environs arising due to urbanization. Environmental quality has always been the most important indicator of the QoL as is emphasized by many studies. (Keles, 2012; Abdel-Hadi, 2012; Derek, 2009). Concurrently, unwelcome and hostile physical environs can lead to the marginalization of sections of society. Inclusive design is vital to the achievement of QoL.

In fast developing third world nations, vital aspects of the microenvironment of buildings are overlooked to the disadvantage of users, onlookers and also the urban fabric. The attitude towards the built is getting increasingly barbaric. The visual, spatial and functional quality of such surrounds is a hindrance to QoL of the citizenry. Frampton's (2009) emphasis on the need to have an aware clientele by the introduction of environmental design as a subject of study at high school level reflects an international crisis of priorities. This scenario raises pertinent questions. Is the significance of the relationship between QoL and the built over-simplified by the public as a whole? Is our primary education unable to cultivate the ability to appreciate the built critically? What position does policy adopt in ensuring responsive teaching-learning environs? These questions incite the need for exploration of the educational objectives of the policy, which is the driving mechanism for ground implementation.

This paper critically examines the directives of the education policy towards the built environs. It studies how QoL has been interpreted and proposed in National Curriculum Framework 2005, the current guideline in India. It investigates the nature of recommendations in the chapter on Classroom and School Environments with a view to understanding its position on QoL from the viewpoint of student-friendliness of school environs.

It suggests an extended appreciation of the concepts stated in NCF 2005 from the view of child-centricity, which shall lead to an improved QoL in the school-going years.

\subsection{Defining Quality of Life in Learning Environs}

\subsection{Constructs of school education}

Learning environs function between academic and administrative controls at the school end and curriculum framework and affiliation requirements control at policy end. These two together have brought the academic achievements of schools to an appreciable level and have apparently met societal expectations. Refer figure 1. This situation is cited and restricted to unaided/ aided private urban Central Board affiliated schools only. 


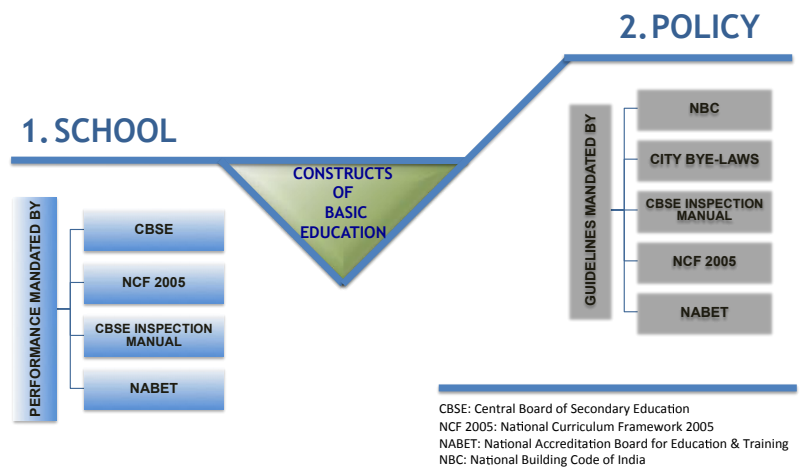

Figure 1: Constructs of basic school education

(Source: Author, 2013)

Core and shell of the school are well-defined tangible assets whose contribution to QoL in the school years is easily understood. The 'intangible in-betweens' lying in the softer realm of psychological and behavioural issues are a neglected arena. These require a closer examination since they contribute towards the well-being of the student users. Refer figure 2 .

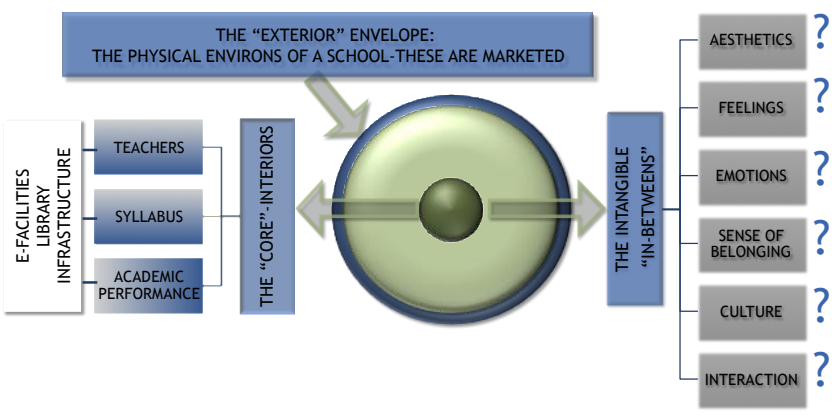

Figure 2: Constituents of a school

(Source: Author, 2013)

\subsection{QoL contributors to school environs}

Recent literature supports the critical need for responsive school environs through an incorporation of various child-centric parameters supportive of the above intangibles. (Khan, 2013; Sanoff, 1996; Fisher, 2001; Gump, 1987; Zhang \& Li, 2011). Responsive school environs can also cultivate an ethically inspired urge for an environmental conscience that is free from external disciplinary pressures at an early age (Keles, 2012) while raising the level of QoL satisfaction. 
Conversely, negotiations with environs designed by adults can make children a marginalized section of society, as they have no voice of their own. A recent doctoral enquiry by the author based on student's evaluation of urban schools in India brings forth the performance of schools for the critical parameters of child-centricity in the Indian context. These are listed in figure 3 (Khan, 2013)

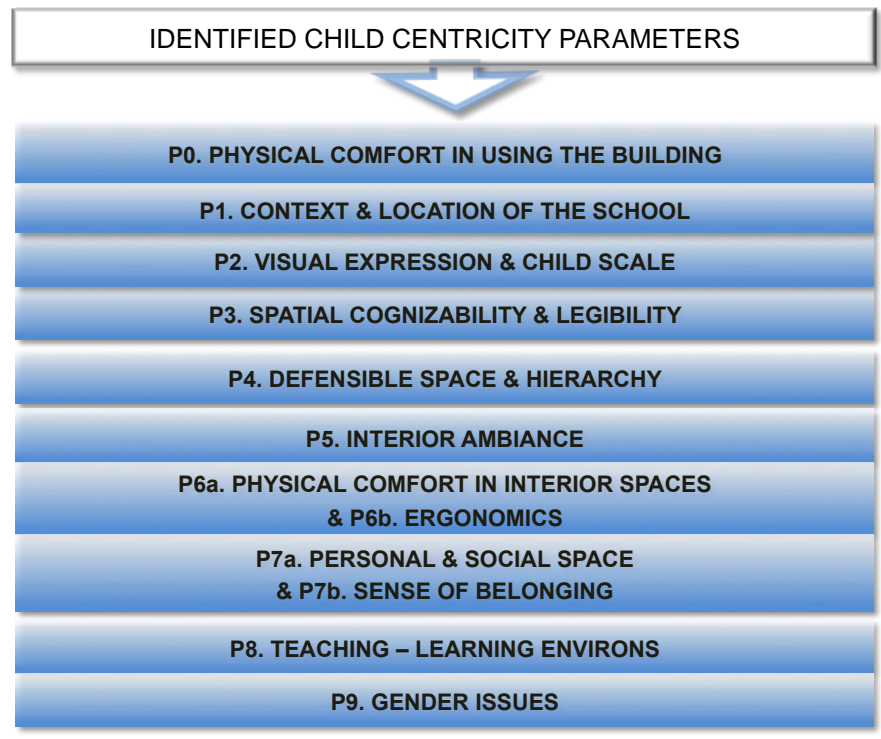

Figure 3: Parameters of Child-Centricity

(Source: Author, 2013)

Table 1: POE results showing child centricity scores in urban Indian schools

\begin{tabular}{|l|l|c|c|c|}
\hline \multirow{2}{*}{$\#$} & CHILD CENTRIC PARAMETERS & RATING WISE CLASSIFICATION OF SCHOOLS & AVERAGE \\
LOOR LEVEL & $\begin{array}{c}\text { VERY GOOD } \\
\text { LEVEL }\end{array}$ & 3 \\
\hline 1 & Physical Comfort in using building & - & 11 & 7 \\
\hline 2 & Visual Expression & - & 7 & - \\
\hline 3 & Child Scale & 4 & 10 & 8 \\
\hline 4 & Spatial Cognizability and Legibility & - & 6 & - \\
\hline 5 & Hierarchy \& Defensible Space & 11 & 3 & 1 \\
\hline 6 & Interior Ambiance & 1 & 12 & 2 \\
\hline 7 & Physical Comfort in Interior Spaces & 7 & 5 & 2 \\
\hline 8 & Ergonomics & 2 & 10 & - \\
\hline 9 & Personal and Social Space & 10 & 4 & 2 \\
\hline 10 & Sense of Belonging & 1 & 11 & 1 \\
\hline 11 & Teaching- Learning Environs & 2 & 11 & \\
\hline
\end{tabular}

**This study was conducted in well established, well performing urban schools with good academic track record and consistent affiliation status.

(Source: Author, 2013) 
Learning environs responsive to the above, contribute positively to the overall development of growing users, physically, mentally and psychologically. These are the fundamental parameters that contribute towards QoL in the learning environs. Table 1 shows the status of these aspects. Factors of physical comfort that are policy supported and regulated have scored well. Conversely, significant contributors towards the making of child-centric environments are poor performers. The status of these parameters in schools brings to question the level of awareness of this concept in its entirety and nature of the policy that supports such affiliation.

\subsection{Understanding Policy Constructs of Indian School Education}

\subsection{Underlying objectives of primary education}

Although primary education has a universal goal, cultural, economic, political ideals and challenges faced by the nation determine the generic direction of education. The uplifting of the nation after 200 years of colonial servitude was envisaged by the visionaries of independence as the focus of educational policy in India. Achievement of economic selfdependence (Halsall, 1998) ("Education as per Mahatma Gandhi"), respect for the rich spiritual legacy of India (O'Connell, 2003; Roy, 2001; Forbes,1997) and addressing ground realities of poverty, societal inequalities and prejudices (Panda,1987; Rai, 1993, Choudhury, 2006) were defined as aims of primary education.

The National Policy on Education, (NPE) (Aggarwal \& Agrawal,1989) lays great thrust on nurturing democratic values enshrined in the Indian Constitution. It addresses the many layers: cultural, lingual and religious, inherent in a geographically unwieldy nation. It aims at nurturing, nourishing and respecting the rich differences of the demography. It also inculcates the essential freedom and equity that marks a true democratic spirit. It is the overarching prerogative and flavour of basic school education in India. As a response to globalization and the technological age, reforms have been initiated by the National Curriculum Frameworks (NCF-s) in conjunction with the NPE. It is a guideline constituted for school education across the nation. This document has been conceived by an expert committee of academicians from various disciplines drawn from the length and breadth of the country. This is intending to be in sync with contemporary concepts, one of which is 'quality of life' (QoL), while retaining the above essence. The concept of QoL is sought to be achieved as national well-being as against that of the individual, in tune with the socialist agenda.

\subsection{Evolution of policy on education}

Evolving policies sought to reform such areas that are spoiling the quality of learning with repercussions on the quality of life when in school. These include 'un-burdening the school bag', 'rejection of competition and achievement of perfection as sole goals', 'non-inclusion', 
'exam oriented learning', 'de-stress the curricula', etc. Each of these represented the malfunctioning of the system and consequent adverse effects on QoL. Policy makers and planners too often overlook environment as an essential component of quality of life for sustainable development (Keles 2011). It is noticeable by its absence in the Indian context. The incorporation of 'quality of life' in NCF 2005, although in an embryonic stage, is a pointer to the economic growth and the need to look beyond into the realm of selfactualization. 'Although QoL has many dimensions, ranging from physical to socio-cultural, psychological and environmental ones, the role of economic factors is undeniably decisive in raising its level. The truth in Keles (2011) statement is reflected in this context. The acknowledgement of the importance and positive contribution of quality built environments is a factor that comes when essentials are satisfied. Thus, this could be a reverse appraisal of the growth and prosperity of a nation. The three-pronged characteristics of the NCF 2005 include an emphasis on relevance, flexibility, and quality. Table 2 shows how constituents integral to these are expected to modernize the system. Due acknowledgement given to a holistic QoL as a vital component of the educational process is of high relevance to this investigation.

The NCF 2005, acknowledges the significance of QoL as an important parameter in the educational process. The comprehensive definition of this concept includes many aspects; a sense of equality, freedom, dignity, enabled-ness all leading to a feel- good social factor. These also enhance QoL in school. The perspective plan of the NCF 2005 has recently introduced a system of accreditation for regulation on the ground by the NABET (Accreditation Standard For Quality School Governance. 2008)

The scope of this paper is restricted to examining recommendations on the nature of physical built. Growing up in child-friendly environments can enhance the quality of life in the school years. They are the backdrop to and the crux of valuable lessons regarding environmental design awareness in a subtle and silent manner.

Table 2: The Three Supports of NCF 2005

\begin{tabular}{|c|c|c|c|}
\hline$\#$ & RELEVANCE & FLEXIBILITY & QUALITY \\
\hline & $\begin{array}{l}\text { Is sought by being in tune } \\
\text { with the national polity \& } \\
\text { ethos. Founding concepts } \\
\text { of the educational policy } \\
\text { revolve around inculcation } \\
\text { of respect for: }\end{array}$ & $\begin{array}{l}\text { Is to manifest in freedom to allow } \\
\text { enable schools to develop within } \\
\text { framework, yet with freedom to } \\
\text { contextualize challenges. This is } \\
\text { essential due to: }\end{array}$ & $\begin{array}{l}\text { This is the special feature of } \\
\text { NCF } 2005 \text {. Quality is a complex } \\
\text { phenomenon due to extreme } \\
\text { polarity between private \& public } \\
\text { sector. Enlisted are essentials to } \\
\text { achieving quality of life by NCF: }\end{array}$ \\
\hline & democracy & $\begin{array}{l}\text { - large national } \\
\text { variations }\end{array}$ & $\begin{array}{ll}- & \text { qualified \& } \\
\text { motivated teachers }\end{array}$ \\
\hline & - $\quad$ secularism & $\begin{array}{l}\text { responsive to multi-lingual/ } \\
\text { cultural nature of nation }\end{array}$ & $\begin{array}{l}\text { negation of exams as sole } \\
\text { criterion for judgment of } \\
\text { quality }\end{array}$ \\
\hline & - cultural plurality & $\begin{array}{l}\text { need to re-interpret \& re-value } \\
\text { the past with reference to } \\
\text { future given the rich legacy of } \\
\text { the ancient nation }\end{array}$ & $\begin{array}{l}\text { relevant \& essential connect } \\
\text { between the curriculum and } \\
\text { larger concerns of life; esp. } \\
\text { the socio-economic and } \\
\text { cultural conditions. }\end{array}$ \\
\hline & - egalitarism & & $\begin{array}{l}\text { Strengthening participatory } \\
\text { democracy and values } \\
\text { enshrined in the constitution }\end{array}$ \\
\hline & - equality & & $\begin{array}{l}\text { emphasis on social context } \\
\text { of education as essential to } \\
\text { quality of life. }\end{array}$ \\
\hline & $\begin{array}{ll}\text { - } & \text { scientific } \\
\text { temperament }\end{array}$ & & $\begin{array}{l}\text { concern for quality of life } \\
\text { in all its dimensions; } \\
\text { peace, environmental } \\
\text { protection \& openness to } \\
\text { social change }\end{array}$ \\
\hline
\end{tabular}




\subsection{A Critical Examination of the National Curriculum Framework Chapter 4 of the NCF 2005 on 'School and Classroom Environments' is of relevance to this investigation and is taken up for critical analysis.}

\subsection{Attitude \& position towards the school built environs}

Table 3: Types of 'Environments' discussed in NCF 2005

\begin{tabular}{|l|l|l|l|}
\hline 1 & 2 & 3 & 4 \\
\hline Physical environs & Enabling environs & $\begin{array}{l}\text { Participatory experience } \\
\text { for all children }\end{array}$ & $\begin{array}{l}\text { Discipline as part of } \\
\text { school environments }\end{array}$ \\
\hline 5 & 6 & 7 & 8 \\
\hline $\begin{array}{l}\text { Space for parents } \\
\text { and community }\end{array}$ & Enriching environs & $\begin{array}{l}\text { Time table as contributor } \\
\text { to school environs }\end{array}$ & Autonomy for teachers \\
\hline
\end{tabular}

(Source: Author, 2013)

Table 4: Aspects, observations and suggestions by NCF 2005 on physical school environs

\begin{tabular}{|c|c|}
\hline 1 & Physical comfort in school setting \\
\hline & i- Brightening classrooms by adequate natural light \\
\hline 2 & Enhancement of physical setting \\
\hline & $\begin{array}{l}\text { i- Dilapidated and dingy school buildings present a drab, un-stimulating physical setting which } \\
\text { needs to be changed by 'simple innovations' by teachers, administrators and architects in a } \\
\text { combined effort. } \\
\text { ii- Enlivening learning spaces by displaying children's work on the walls of the classroom as well as } \\
\text { different parts of school with easy physical as well as visual accessibility } \\
\text { iii- Nature of such displays should be changeable, so that preparing and participating in putting } \\
\text { them up can be valuable learning activity for the children. } \\
\text { iv- Keeping school spaces clean and in order to ingrain a sense of collective responsibility for a } \\
\text { public space informed by values of equality and respect for labour of all types. }\end{array}$ \\
\hline 3 & Essential facilities \\
\hline & $\begin{array}{l}\text { i- Playgrounds are a must for outdoor learning activities, as lack of such facility compromises the } \\
\text { quality of learning through the curriculum. } \\
\text { ii- Classrooms shall have flexible layouts so that groups can be formed for storytelling or watching } \\
\text { a radio or TV broadcast in a group. This can be achieved by acquiring small movable desks and } \\
\text { chairs or rugs that can be moved around. Heavy metal benches that are largely being used } \\
\text { currently in most schools must be banned. } \\
\text { iii- There must be adequate space for keeping books, belongings and physical comfort of children } \\
\text { must be catered to in the furniture. } \\
\text { iv- Corners of classrooms shall be used as resource nooks for story books, riddles, puzzles or } \\
\text { other learning materials. (Source: Author, 2013) }\end{array}$ \\
\hline 4 & Physical Spaces as Learning Tool \\
\hline & $\begin{array}{l}\text { i- Maximum educational value should be derived from the school buildings, since they are the most } \\
\text { expensive assets of a school by using creative and practical solutions. This practice needs to be } \\
\text { applied in all cases of repairing, upgrading of existing or designing of new schools. } \\
\text { ii- Buildings can offer a multi sensory experience to enrich the textbook or blackboard as primary } \\
\text { sources of learning. Spatial dimensions, textures, shapes, angles, movements and spatial } \\
\text { attributes like inside-outside, symmetry, up-down, can be used to communicate some basic } \\
\text { concepts of language, maths and environment. } \\
\text { iii- While window grills of classrooms can be used to understanding fractions and angles, the ceiling } \\
\text { fan painted in a range of colours, can be a source of enjoying ever changing formations! Geometric } \\
\text { patterns on floor can be used for activities. } \\
\text { iv- Other objects around the school premises can also be used as a teaching tool, such as the } \\
\text { shadow of flagpole as a sundial, or an adventure playground using discarded tyres. } \\
\text { v- To encourage the children to explore and actually see and practice rain water harvesting etc. }\end{array}$ \\
\hline
\end{tabular}


Table 3 enlists various shades of 'Environments' discussed in NCF 2005. The realm of the built environment, addressed by architects and planners, is confined to the first sub-section. A concise summarization of aspects physical environs addressed in the NCF 2005 and observations and remedial suggestions specified for them are listed in Table 4.

It is unfortunate that the singular chapter dedicated to learning environs does not elaborate upon robust recommendations for built environments. Sub-section two on 'enabling' environment details on the achievement of equality, social justice and respect for diversity, dignity and rights of children, so that children can feel secure. This is a vital criterion for the quality of life in school. In the multi-layered Indian context, the creation of an atmosphere of equality and social acceptance rightly defines QoL.

Subsection three on 'participation' elaborates on egalitarianism, secularism, equality and inclusion as core principles of democracy. This is explained through 'empowering the weak and marginalized,' 'community participation', 'celebrating diversity', 'tiding over sociophysical and attitudinal barriers', 'inculcation of mutual respect and interdependence', etc. The agenda pinpoints upon the issue of social equality. All the other sub- sections also inform this theme.

\subsection{A critical analysis of the NCF-2005 \& recommendations}

A critical appraisal of the policy framework pinpoints following gaps:

The issue of responsive learning environments has been oversimplified

(i) Acknowledging the critical need for child-friendly environs, the document hastily offers remedies for maximum 'educational gratification' in a rather unsophisticated manner. For example, using tile pattern on the floor as a chessboard and geometric patterns on window grills.

The immature emphasis of specific design elements overlooks the magnanimous role of the built environs in opening up unexplored dimensions of spatial experience. The lack of supportive E-B research is evident by its absence. Policy guidelines lag in understanding the intrinsic relation between built environment and its positive psychological impact on human behaviour.

(ii) The exhaustive list of contributors to NCF 2005 composes of honoured experts mainly from academia. It exposes a lack of inter-disciplinary approach. Studied inputs from architecture and planning discipline, would help in achieving the responsive design.

The NCF 2005 acknowledges that 'no single norm of capacity, personality or aspiration can serve the emerging scenario of children from different socio-economic and cultural backgrounds and different abilities.'

The curriculum policy contradicts itself in applying the yardstick of a singular system of school environs for the varied range of schools. The socialist spirit of the nation, selfconsciously avoids a robust discussion, leaving many issues unattended. The changing economic and global scenario demands that there be a simultaneous evolution of schools at various levels. This is reflected and evidenced in Table 4. 
The current affiliation criteria by NABET that stops short at emphasizing only essential requirements such as good light, ventilation, etc. In a developing nation, QoL has a very stark definition, and such is the conceptual \& intellectual limitation of the policy guideline. The NCF 2005 addresses the requirements of the 'very young' and most suggestions aim at 'children'.

This lopsided view should be remedied by addressing the unique requirements of the various levels of school such as primary, secondary and high school. This would also facilitate the development of environs in consonance with the changing spatial requirements- both physical and psychological.

The NCF 2005 emphasizes on a policy of inclusion in the education system. 'Opportunities to display talents and share with peers nurtures motivation and involvement among children. In our schools, we tend to select some children over and again, resulting in small groups becoming self-confident and visible while others experience repeated disappointment and a longing for recognition and approval.'

The statement is clearly indicating a scale issue. This has resulted in the restricting the class strength to 40 students, a stricture that is mostly violated. The scale of the physical environs is also an issue. Large schools have capacities up to 3500-4000 students, with schools working single shift. It makes the size of the school unwieldy and violates 'scale' completely. It is detrimental both from the point of view of inclusion as policy states as well as from the point of view of a sense of ease and psychological comfort for the young students. It is an issue where policy and accreditation have to perform in tandem.

The NCF 2005 acknowledges the long hours spent in school and the need for an optimum level of comfort and a congenial working space with minimum facilities that include essential furniture, basic amenities (toilets, drinking water) and so on. The nature of economic disparities makes for an understanding of 'congenial' as bare minimum amenities. Its failure comes at the point where need to look beyond into further child-centric enhancement of the built environ to the enrichment of the cognitive capacities of the learners is almost consciously ignored. Most efforts on these vital basics are essential in Indian schools.

The NCF 2005 weaves its recommendations through a vocabulary consisting of such appropriate terminology, which if applied to the built environs can support the core essence of the document still further but are ignored at best.

It encourages the participation of children into a national culture of egalitarianism, democracy, secularism and equality, but fails to include some critical areas. It also encourages values of inclusion and empowerment of the weak and marginalized \& their participation in the development of a collective voice as crucial to the success of schooling.

This study recommends that the policy be made comprehensive by an inclusion of school built environs since this socio-cultural realm is a vital aspect of school life. Also, it should mandate universal design towards impartial selection and the inclusion of children with disabilities. This shall absorb differently challenged children into the mainstream. 
The NCF states, 'pupils own the school just as the teachers'. Thus, it is vital to delegate the responsibility of maintaining order in the school to children through codes of selfgovernance, decision-making and a democratic manner of functioning. Such can be positive lessons, rather than it being the prerogative of the teachers.

Participation in the maintenance and upkeep of the school environs is also valuable learning making them shareholders and fostering a sense of belonging and responsibility for their own school. It is a sure way to tackle the nuisance of vandalism that most schools face. Sharing and caring for school facilities can be essential learning for responsible future citizens.

The NCF 2005 states, 'Enabled learning environs are ones where there is the absence of fear and feeling of security through relationships of equality and equity'. An enabled school environ, is also one which has a defensible spatial experience. Visual connectivity, easy way-finding and a hierarchical division of school spaces shall lead to a feeling of being secure and give an opportunity to use facilities while discouraging peer pressures and bullying. The NCF 2005 acknowledges that the school is a structured space for guided learning, but the process of constructing knowledge is a continuous one, which goes on even outside the school. The involvement of the local community in such enrichment is encouraged. While this aspect is appreciated, the lessons that can be derived by treating the school as a 3-D live model/ open textbook have been missed out altogether. This paper suggests such inclusion for value addition.

NCF 2005 discusses, 'Learner-friendly', 'equality \& equity', 'positive experience', 'inclusion', 'owning of school by students', 'space for parents and community', etc. Unfortunately, all these are restricted to socio-cultural and economic perspective only. The issue of built environs continues as a grey area, to be remedied for a holistic completion of the chapter.

The limitation of the NCF is that, beyond its focused and limited scope, it does not explore an application of the many concepts it states. It is also a pointer to what aspects of living are endorsed by the national ethos as 'QoL'. While these are certainly essential to lead a happy and relaxed childhood, with improving economic situations especially in urban areas, enrichment through the medium of the spatial built is vital.

\subsection{Conclusion}

In recent times, while there is an evolving consciousness regarding the role of the school built environs in the educational process, the contribution of a responsive built towards QoL is generally underestimated in a developing country beleaguered with myriad economic issues. A semblance of awakening towards QoL manifests itself in the National Curriculum Framework 2005, although in a nascent stage. In the Indian situation, this concern solicits deep reflection and requires urgent affirmative action. The major focus of the curriculum framework is directed towards a holistic understanding of a democratic way of life. Yet, the 
current narrowly construed definition of 'democratic' needs transformation. The policy exposes an inability to address the range of extremities oversimplifying the complexity that India represents. It generalizes situations in haste into 'one-shot' recommendations.

The paper recommends reforms by a magnanimous interpretation of democratic values. It emphasizes for participation in the development of one's environs right from school years. In the creation of responsible and aware citizens, an understanding of the vital role of the microenvironment of school is important. It urges simultaneity in addressing issues within policy framing. The study also recommends an interdisciplinary synthesis by an inclusion of architects and planners as important contributors to the conception of built environs. These are conspicuous by their absence in the panel of experts. The paper stresses the critical need for the creation of child-centric environments by policy and its implementation through affiliation requirements for schools. Such recommendation shall go a long way in shaping QoL supportive environs in the developing world.

\section{References}

Abdel-Hadi. (2012). Culture, quality of life, globalization and beyond. Procedia-Social and Behavioural Sciences, $50,11-19$.

Aggarwal, J. C., \& Agrawal, S. P. (1989). National policy on education: Agenda for India 2001. New Delhi, India: Concept Publishing Company.

Choudhury, S. (2006). Educational philosophy of Dr.Sarvepalli Radha Krishnan. India: Deep and Deep Publications.

Derek, G. et al., Eds.(June 2009). "Quality of life". dictionary of human geography (5th ed.). Oxford: WileyBlackwell.

Fisher, K. (2001). Building better outcomes: The impact of school infrastructure on student's outcome \& behaviour. Department of Education, Training and Youth Affairs. Australia.

Forbes, S. H. (1997). Jiddu Krishnamurti and his Insights into Education. Retrieved 3 29, 2011, from www.infed.org: http://www.infed.org/thinkers/et-krish.htm

Frampton, K.(2009). Seven points for the millennium: An untimely manifesto. Keynote Speech.UIA 2009.

Gump, P. (1987). School \& classroom environments, Handbook of Environmental Psychology, 1, 691-732.

Keles, R.(2012). The quality of life and the environment. Procedia-Social and Behavioural Sciences, 35, 23-32.

Khan, (2013). A study of child centricity in urban schools through post occupancy evaluation. Unpublished Doctoral Research. VNIT, India.

Marans, R.(2012). Quality of urban life studies: An overview and implications for environment-behaviour research. Procedia-Social and Behavioural Sciences, 35, 9-22. 
O'Connell, K. (2003). Rabindranath Tagore on Education. Retrieved 3 29, 2011, from http://www.infed.org/thinkers/tagore.htm

Rai, L. L. (1993). The problems of National Education in India. Lala Lajpat Rai, 15, 324.

Roy, S. D. (2001, 7). Education in the vision of Swami Vivekananda. Retrieved 3 29, 2011, from www.esamskriti.com: http://www.esmskriti.com/essay-chapters/education-in-the-vision-of-swami-vivekananda1.aspx

Sanoff, H. (1996). Designing a Responsive School. The School Administrator. 53(6) 18-22.

Tagore, R. (1985). Rabindranath Tagore: Selected poems. (W. Radice, Trans.) Penguin Books, UK.

Zhang, H. \& Li, M. (2011). Environmental characteristics of children's neighbourhood activities. Asian Journal of Environment- Behaviour Studies, 2(4), 40-50.

Accreditation Standard For Quality School Governance. (2008). National accreditation board for education and training, New Delhi, India.

"Education as per Mahatma Gandhi". (n.d.). Retrieved 2 11, 2011,from www.mkgandhi.org: http://www.mkgandhi.org/edugandhi/index.htmwww.ncert.nic accessed at 5.30 pm on 5.09.2012. 